Summer 2006

\title{
Why Religion in Politics Does Not Violate la Conception Américaine de la Laïcité
}

Michael J. Perry

Emory University

Follow this and additional works at: https://www.repository.law.indiana.edu/ijgls

Part of the Constitutional Law Commons, and the Religion Law Commons

\section{Recommended Citation}

Perry, Michael J. (2006) "Why Religion in Politics Does Not Violate la Conception Américaine de la Laïcité," Indiana Journal of Global Legal Studies: Vol. 13 : Iss. 2 , Article 9.

Available at: https://www.repository.law.indiana.edu/ijgls/vol13/iss2/9

This Symposium is brought to you for free and open access by the Law School Journals at Digital Repository @ Maurer Law. It has been accepted for inclusion in Indiana Journal of Global Legal Studies by an authorized editor of Digital Repository @ Maurer Law. For more information, please contact rvaughan@indiana.edu.

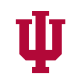

JEROME HALL LAW LIBRARY

INDIANA UNIVERSITY

Maurer School of Law
Bloomington 


\title{
Why Religion in Politics Does Not Violate la Conception Américaine de la Laïcité*
}

\author{
Michael J. Perry**
}

\begin{abstract}
La conception Américaine de la laïcité consists principally of a constitutional norm - the nonestablishment norm - and of the law that the U.S. Supreme Court has developed in the course of enforcing the norm. The nonestablishment norm forbids government-both the national government and state government-to "establish" religion. American laïcité also consists of what we may call "the morality of liberal democracy." My aim in this essay is to explain why religion in politics does not violate American laïcité; more specifically, my aim is to explain why political reliance on religiously grounded morality violates neither the nonestablishment norm nor the morality of liberal democracy.
\end{abstract}

\section{INTRODUCTION}

La conception Américaine de la lä̈ité consists principally of a constitutional norm-the nonestablishment norm-and of the law that the U.S. Supreme Court has developed in the course of enforcing the norm. The nonestablishment norm forbids government-both the national government and state government-to "establish" religion.' American laïcité also consists of what we may call "the morality of liberal democracy." My aim in this essay is to explain why religion in politics does not violate American laïcité; more specifically, my

*For an earlier, longer, and more heavily annotated version of the arguments presented in this essay, see Michael J. Perry, Under God? Religious Faith and Liberal Democracy 20-52 (2003).

**Robert W. Woodruff Chair in Law, Emory University; Senior Fellow, Law and Religion Program, Emory University.

1. The U.S. Constitution famously declares, in the First Amendment, that "Congress shall make no law respecting an establishment of religion, or prohibiting the free exercise thereof ...." Yet, it is settled constitutional law that not just Congress but the entire national government-and not just the national government but state governments, too-may not establish religion or prohibit the free exercise thereof. See Michael W. McConnell, Accommodation of Religion: An Update and Response to the Critics, 60 Geo. Wash. L. Rev. 685, 690 (1992) ("The government may not 
aim is to explain why political reliance on religiously grounded morality violates neither the nonestablishment norm nor the morality of liberal democracy.

Imagine a legislator who is inclined to vote against a proposal to extend the benefit of law to same-sex unions. (Or, if you prefer, imagine a legislator who is inclined to vote for a proposal to criminalize abortion.) She is an admirably conscientious legislator, and she therefore wonders what weight, if any, she and her fellow legislators may put on their religiously grounded belief that homosexual sexual conduct (or abortion) is immoral. More precisely, she wonders whether the nonestablishment norm-or, if not the nonestablishment norm, then the morality of liberal democracy - forbids them to disfavor conduct on the basis of religiously grounded moral belief. My aim here is to explain why legislators and other policymakers do not violate American laïcité-that is, why they violate neither the nonestablishment norm nor the morality of liberal democracywhen they outlaw particular conduct, or otherwise disfavor it, on the basis of a religiously grounded belief that the conduct is immoral —a religiously grounded belief, for example, that same-sex unions are immoral. ${ }^{2}$

'establish' religion and it may not "prohibit' religion." (footnote omitted)). McConnell explains, in a footnote attached to the word "establish," that:

The text lof the First Amendment] states the "Congress" may make no law "respecting an establishment" of religion, which meant that Congress could neither establish a national church nor interfere with the establishment of state churches as they then existed in the various states. After the last disestablishment in 1833 and the incorporation of the First Amendment against the states through the Fourteenth Amendment, this "federalism" aspect of the Amendment has lost its significance, and the Clause can be read as forbidding the government to establish religion.

Id. at $690 \mathrm{n} .19$.

2. In the context of this essay, by a moral belief that is "religiously" grounded, I mean a moral belief that is rooted, in whole or in part, in one or more of three ideas:

- The idea of a God-inspired text (or texts), like the Bible, believed to teach moral truth-if not all moral truth, at least all the moral truth one needs to be saved.

- The idea of a God-anointed figure (or figures), like the Pope, believed to teach moral truth.

- The idea of a God-created and -maintained order-including, in particular, a God-fashioned human nature-believed to be a fundamental criterion of moral truth.

The religious grounding vel non of a moral belief is person-relative: A moral belief that is religiously grounded for one person may not be for another. Two persons may both believe that 


\section{The Nonestablishment Norm}

The idea of an "established" church is a familiar one. For Americans, the best known and most relevant example is the Church of England, which, from before the time of the American founding to the present, has been the established church in England. (Though the Church of England was much more established in the past than it is today.) In the United States, however, unlike in England, there may be no established church. At its uncontroverted core, the nonestablishment norm forbids government to enact any law or adopt any policy that treats any church as the official church of the political community. (When I say "any church," I mean to include any range of theologically kindred churches-for example, Christian churches, which, though denominationally diverse, are sometimes referred to in the singular, as "the Christian church.") To say that government may not establish religion is centrally to say that government may not act for the purpose of bestowing legal favor or privilege on any

homosexual sexual conduct is immoral but each for a different reason-one, solely for a religious reason, the other, solely for a nonreligious (secular) reason. In the strong sense in which I mean it here, a person's moral belief is religiously "grounded" if and only if she accepts the moral belief because she accepts one or more religious premises that support the belief-for example, the premise that the Bible teaches that the conduct is immoral —and if she would not accept the belief if she did not accept the supporting religious premise or premises. Thus, a person's moral belief is not religiously grounded, in this strong sense, if she would accept the belief even if she did not accept any supporting religious premise-that is, if she would accept it solely because she accepts one or more nonreligious (secular) premises that support the belief.

One more clarification: In the strong sense in which I mean it here, to make a political choice (e.g., to enact a law) "on the basis of" a belief - to base the choice on the belief-is to make a political choice that one would not make in the absence of the belief. (To make a political choice partly, not solely, "on the basis of" a belief is still to make a political choice that one would not make in the absence of the belief.) To rely on a belief in making a political choice is not necessarily to base the choice on the belief: One may be relying on the belief as principal or merely as additional support for a choice that one would make, on the basis of some other ground, even in the absence of the belief. The claim that one may not base a political choice on a belief of a certain kind-for example, religiously grounded belief-is therefore weaker, in the sense of less restrictive, than the claim that one may not rely on the belief at all, that one may not put any weight whatsoever on the belief, in making a political choice. If the weaker (less restrictive) claim cannot be sustained, then a fortiori the stronger (more restrictive) claim cannot be sustained either. If, as I conclude in this essay, the weaker claim cannot be sustained that, under the nonestablishment norm, government-in particular, legislators and other policymakers-may not disfavor conduct on the basis of a religiously grounded belief that the conduct is immoral, it is unnecessary to focus on the stronger nonestablishment claim that in disfavoring the conduct government may not rely on the belief at all. 
church-that is, on any church as such-in relation to any other church (or churches). More precisely: Government may not act for the purpose of favoring any church in relation to any other church on the basis of the view that the favored church is, as a church or as a community of faith, better along one or another dimension of value - truer, for example, or more efficacious spiritually, or more authentically American. The nonestablishment norm deprives government of jurisdiction to make judgments about which church, if any, is, as such, better than another church. The norm requires government to be agnostic about which church-which community of faith-is better; government must act without regard to whether any church is in fact better. ${ }^{3}$ In particular, government may not privilege, in law or policy, membership in any church-in the Fifth Avenue Baptist Church, for example, or in the Roman Catholic Church, or in the Christian church generally; ${ }^{+}$nor may it privilege a worship practice-a prayer, liturgical rite, or religious observance-of any church. ${ }^{5}$

In forbidding government to bestow legal favor on a church (or on more than one church) as such-in forbidding it, in particular, to privilege either membership in or a worship practice of a church-the nonestablishment norm does not forbid a legislature (or other policymaker) to disfavor conduct on the basis of religiously grounded moral belief: That a legislature has voted to disfavor same-sex unions, for example, on the basis of a religiously grounded belief that same-sex unions are immoral in no way entails that the legislature has privileged either membership in or a worship practice of a church or that it has otherwise bestowed

3. As U.S. Supreme Court Justice William Brennan once put it: "It may be true that individuals cannot be 'neutral' on the question of religion. But the judgment of the Establishment Clause is that neutrality by the organs of government on questions of religion is both possible and imperative." Marsh v. Chambers, 463 U.S. 783, 821 (1983) (Brennan, J., dissenting) (footnote omitted).

4. For an example of a position that privileges the Christian church generally, see Other Faiths Are Deficient, Pope Says, Tablet (London), Feb. 5, 2000, at 157 ("The revelation of Christ is 'definitive and complete,' Pope John Paul affirmed to the Congregation for the Doctrine of the Faith, on 28 January. He repeated the phrase twice in an address which went on to say that nonChristians live in 'a deficient situation, compared to those who have the fullness of salvific means in the Church'."). The harsh doctrine that there is no salvation outside the church has been revised, however. "[Pope John Paul II] recognised, following the Second Vatican Council, that nonChristians can reach eternal life if they seek God with a sincere heart. But in that 'sincere search' they are in fact 'ordered' towards Christ and his Church." Id.

5. Cf. Douglas Laycock, Freedom of Speech That Is Both Religious and Political, 29 U.C. Davis L. Rev. 793, 812-13 (1996) (arguing that "[a]t the core of the Establishment Clause should be the principle that government cannot engage in a religious observance or compel or persuade citizens to do so"). 
legal favor on a church. Moreover, the law that the U.S. Supreme Court has developed in the course of enforcing the nonestablishment norm:

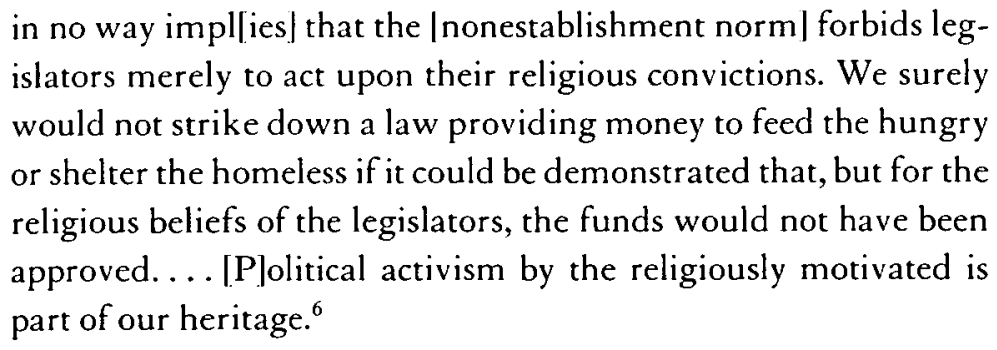

However, that the U.S. Supreme Court has not yet construed the nonestablishment norm to forbid government to disfavor conduct on the basis of religiously grounded moral belief does not mean that the Court should not so rule in the future. So let me explain why the Court should not so rule. Consider, first, the practical impediments to construing the nonestablishment norm to disable government - to disable legislators and other policymakers-from outlawing or otherwise disfavoring conduct on the basis of a religiously grounded belief that the conduct is immoral.

- For virtually every moral belief on which a legislature might be tempted to rely in disfavoring conduct-for example, the belief that abortion, or homosexual sexual conduct, is immoral-it is the case that although for some persons the belief is religiously grounded (grounded on a religious premise or premises), for others the belief is not religiously grounded but, instead, is grounded wholly on a secular (nonreligious) premise(s). For still others, the belief is supported both by a religious premise and, independently, by a secular premise. How, then, is a court to decide whether a law banning abortion (for example) would have been enacted even in the absence of the religious premise? Indeed, one or more legislators may well be uncertain whether they would have supported the law in the absence of the religious premise. They may be uncertain, for example, whether

6. Edwards v. Aguillard, 482 U.S. 578, 615 (1987) (Scalia, J., dissenting). 
they would credit the supporting secular premise if they did not al ready credit the supporting religious premise.

- In the unlikely event there is a confident answer to such counterfactual inquiry, is it prudent to fashion a nonestablishment requirement the judicial enforcement of which could easily lead to this state of affairs: One state's antiabortion law is adjudged unconstitutional by a court because in the court's opinion the law probably would not have been enacted in the absence of the religious premise, but another state's virtually identical antiabortion law is adjudged constitutional by a different court because in the court's opinion the law probably would have been enacted in the absence of the religious premise?

- Moreover, is it prudent to fashion a nonestablishment requirement the likely principal yield of which is that legislatures would engage in strategic behavior - they would trumpet secular premises-aimed at making it appear that the antiabortion law would have been enacted even in the absence of the religious premise?

The judiciary could steer around such obstacles-it could opt for a "second best" solution - by construing the nonestablishment norm to require, not that the law in question would have been enacted even in the absence of a religious premise, but only that the moral belief on which the legislature based the law, a moral belief that for many persons is religiously grounded, have an independent secular ground - that it be a moral belief that for some persons is not religiously grounded. ${ }^{7}$ But this requirement is so weak as to be inconsequential: What moral belief on which a legislature in the United States is likely to rely, in banning or otherwise disfavoring conduct, lacks a secular ground? Consider, for example, both the belief that abortion is immoral and the belief that same-sex

7. See Kathleen M. Sullivan, Religion and Liberal Democracy, 59 U. CHr. L. Rev. 195, 197 (1992) ("IT The negative bar against establishment of religion implies the affirmative 'establishment' of a civil order for the resolution of public moral disputes.... [P]ublic moral disputes may be resolved only on grounds articulable in secular terms."). Recall that, as I noted earlier, the religious grounding vel non of a moral belief is person-relative: A moral belief that is religiously grounded for one person may not be for another. A belief that conduct is immoral is religiously "grounded" for a person if she would not believe that the conduct is immoral if she did not credit one or more religious premises that support the belief-for example, the premise that the Bible (understood as God-inspired and therefore authoritative) teaches that the conduct is immoral. 
unions are immoral: Neither belief lacks a secular ground. Although many who believe that abortion is immoral do so only on the basis of a religious premise (or premises), others do so on the basis of a secular premise as well as on the basis of a religious premise; indeed, some do so only on the basis of a secular premise. The same holds true for many who believe that same-sex unions are immoral. Indeed, both some who affirm that abortion is immoral and some who affirm that same-sex unions are immoral are not religious believers.

The judiciary could respond to this difficulty by ruling that the nonestablishment requirement (i.e., the "second best" requirement) should be not merely that the moral belief on which the legislature based the law have an independent secular ground, but that the independent secular ground be plausible. There is, however, a serious problem with this requirement: The secular grounds of widely controversial moral beliefs are typically both contestable and contested. Authorizing judicial inquiry into the "plausibility" of the secular ground of a widely controversial moral belief comes perilously close to having judges act as the supreme arbiters of controversial moral beliefs. Such a judicial role is scarcely a desirable state of affairs in a democracy. This is not to deny that in a constitutional democracy, a court should be prepared to substitute its constitutional judgment for the constitutional judgment of a legislature or other part of government. Nor is it to deny that some constitutional provisions rule out, as a basis of political choice, some moral judgments, whether or not those judgments are religiously grounded. (For example, the Fourteenth Amendment to the U.S. Constitution rules out, as a basis of political choice, the judgment that it is immoral for a white person to marry a person who is not white. ${ }^{8}$ ) My point is simply that we should be wary about fashioning a constitutional requirement

8. See Loving v. Virginia, 388 U.S. 1 (1967) (overturning a law forbidding interracial marriages in violation of the Fourteenth Amendment). For government to disfavor conduct on the basis of any racist belief would be for it to violate the Fourteenth Amendment. See Michael J. Perry, We the People: The Fourteenth Amendment and the Supreme Court 88-97 (1999). Government may not disfavor conduct based on a racist belief-for example, the belief that interracial marriage is immoral-not because the belief is false, or believed to be false, but simply because for government to do so would be for it to act unconstitutionally; it would be for government to make a judgment that it is not constitutionally free to make. Of course, that the Constitution forbids government to make a particular judgment-that interracial marriage is immoral, for example, or that the Pope is the Antichrist and that Roman Catholicism is a false religion-may well be due, at least in part, to the fact many believe the judgment to be false. But it may also be due solely to the fact that many believe that whether or not the judgment is false, it is no part of the proper business of government to make the judgment. 
the judicial enforcement of which practically invites judges to substitute their moral judgments for the moral judgments of others, including legislators and other policymakers.

There is yet another important reason to be wary about construing the nonestablishment norm to forbid government to disfavor conduct on the basis of a moral belief that, though religiously grounded, lacks a plausible, independent secular ground. (A fortiori, it is a reason to be wary about construing the nonestablishment norm even more radically, to forbid government to disfavor conduct on the basis of a religiously grounded moral belief whether the belief also has a plausible, independent secular ground.) Unlike the other reasons, this reason for wariness is not about practical impediments or proper judicial role. It is about impartiality between religious grounds and secular grounds for moral belief; it is also about the equal citizenship of religious believers. In that sense, this reason is about first principles and is therefore the most fundamental reason of all to reject a construal of the nonestablishment norm according to which government may not disfavor conduct on the basis of a moral belief that, though religiously grounded, lacks plausible, independent secular grounding.

Consider three fundamental moral questions: (1) What entities-in particular, what human beings-ought we to care about? (2) What is truly good for those we should care about-and what is bad for them? (3) And how should we resolve conflicts between goods-in particular, between what is good for some we should care about and what is good for others we should care about? For many religious believers in the United States, no answer to one or more of these questions is as plausible, if plausible at all, as a religiously grounded answer. For example: For many religious believers, no secular warrant for the claim that we should care about each and every person - that each and every person has inherent dignity and is therefore inviolable-is plausible; only a religious warrant is plausible. ${ }^{9}$ Therefore, to construe the nonestablishment norm to forbid government to disfavor conduct on the basis of a moral belief that, though religiously grounded, lacks, or may lack, a plausible, independent secular ground makes no sense at all to such believers, for whom the only plausible response to one or more of these three fundamental moral questions, or at least the most plausible response, is a religiously grounded one.

9. See Michael J. Perry, The Morality of Human Rights: A Nonreligious Ground?, 54 EMory L.J. 97, 149-50 (2005). 
But others, including some religious believers, may wonder what sense it makes, if any, to read the nonestablishment norm to forbid government to privilege one or more churches while leaving a legislative majority free to disfavor conduct on the basis of a moral belief that has only a religious ground-a ground that, almost certainly, only some churches accept. Is this distinction-between, on the one side, government's privileging one or more churches and, on the other, government's disfavoring conduct on the basis of a moral belief that has only a religious ground - merely formalistic: Is it a distinction without a difference? Does the distinction bear the weight I am putting on it here? A fair question-to which the answer is yes, the distinction does bear the weight. It does make sense to read the nonestablishment norm as I do. Let me explain.

Government can get along very well without privileging one or more churches-without privileging, for example, either membership in or a worship practice of one or more churches. There is simply no practical need for it to do so; indeed, there is a practical need for it not to do so. (Or so many of us Americans believe. ${ }^{10}$ ) But legislators cannot get along without relying on moral beliefs-because they must often resolve controversies that are fundamentally and ineliminably moral in character. One may respond-especially one who rejects religious belief - that legislators can get along without relying on moral beliefs that lack a plausible, independent secular ground. From the perspective of many religious believers in the United States, however, to forbid legislators to disfavor conduct on the basis of a moral belief with a religious ground unless the belief also has a plausible, independent secular ground (i.e., for the judiciary to strike down the political choice if it lacks a plausible, independent secular ground) would be to import into the Constitution a controversial conception of the proper relation between morality and religion, according to which morality can and should stand independently of religion. For some Americansespecially for some who are not religious believers-that conception of the proper relation between morality and religion is attractive. But for the large majority of Americans who are religious believers, their most fundamental moral judgments are inextricably rooted in their religious faith; moreover, they are

10. See Douglas Laycock, The Benefits of the Establishment Clause, 42 DePaul L. Rev. 373, 380 (1992) ("There is no need for the government to make decisions about Christian rituals versus Jewish rituals versus no religious rituals at all. For government to make that choice is simply a gratuitous statement about the kind of people we really are. By making such statements, the government says the real American religion is watered-down Christianity, and everybody else is a little bit un-American."). 
skeptical that those judgments can stand — can be warranted-independently of religious faith, whether their own religious faith or some religious faith. For such Americans, to construe the nonestablishment norm to forbid legislators to base a political choice on a religiously grounded moral belief unless the belief also has a plausible, independent secular ground would not only not make sense; it would unfairly deprivilege religious faith, relative to secular belief, as a ground of moral judgment-and unfairly deprivilege, too, therefore, those moral judgments that, in their view, cannot stand independently of religious faith. Such a construal-while understandably appealing to some who reject religious faith-is widely and deeply controversial. Such a construal is, in a word, sectarian and has no claim on the large majority of Americans for whom religious faith and moral judgment are often inextricably related.

In deciding whether to disfavor conduct (at least partly) on the basis of the belief that it is immoral, one or more legislators - even a majority of them-may answer the question whether the conduct is in fact immoral on the ground or grounds in which they have the most confidence, in which they place the most trust, and then make their political choice accordingly. In particular, they may do so whether or not the ground is religious-and, so, even if it is religious. Of course, this is not to say that the political choice they make-for example, a choice disfavoring racial intermarriage or same-sex marriage-is necessarily constitutional. The choice may violate a constitutional provision other than the nonestablishment norm.

Now, nothing I've said is meant to deny that religious grounds for moral beliefs are destined to be controversial in a religiously pluralistic society like the United States. But secular grounds for moral belief are destined to be controversial"sectarian"-too.

The challenge to the advocate of restraint is that of discovering some relevant difference between religious and secular norms in virtue of which it is reasonable to advocate restraint regarding the former but not the latter. Only by identifying some such relevant difference can the advocate of restraint nonarbitrarily exclude religious but not secular grounds from political deliberation. ${ }^{11}$

In the context of this essay, the question is whether any "relevant difference" warrants a construal of the nonestablishment norm according to which (a) government is free to disfavor conduct on the basis of a moral belief that has a plau-

11. Christopher J. Eberle, Why Restraint Is Religiously Unacceptable, 35 Relicious Stud. 247, $261-62$ (1999). 
sible, independent secular ground, no matter how controversial the secular ground may be, and without regard to whether the moral belief also has a religious ground, but (b) government is not free to disfavor conduct on the basis of a moral belief that has a religious ground, no matter how ecumenical (i.e., widely shared among religious denominations) the religious ground may be, unless the moral belief also has a plausible, independent secular ground. (It would beg the question to invoke the nonestablishment norm in support of that construal of the norm: The question at hand is precisely whether the nonestablishment norm should be so construed. The claim that such a construal of the nonestablishment norm is axiomatic for us Americans is simply mistaken.) One needs a most compelling argument to warrant such a problematic-indeed, sectarian-reading of the nonestablishment norm.

In the absence of such an argument, there is no warrant for construing the nonestablishment norm to mandate discrimination against religiously grounded moral beliefs that lack a plausible, independent secular ground. Indeed, such discrimination is, as a practical matter, discrimination against many religious believers, namely, those whose most fundamental moral beliefs (all or some of them) fit the profile: beliefs that (a) are religiously grounded, but that (b) have no plausible, independent secular ground. According to the nonestablishment norm, thus construed, such believers would have only a kind of second-class citizenship; they would not have a citizenship equal to that of citizens whose most fundamental moral beliefs are secularly grounded. ${ }^{12}$ As I said, one needs a compelling argument to warrant this reading of the nonestablishment norm-a reading that compromises the equal citizenship of many religious believers. I myself am aware of no such argument. ${ }^{13}$

As a last resort, one might want to suggest that under my reading of the nonestablishment norm, according to which government may disfavor conduct on the basis of a religiously grounded moral belief for which there may be no plausible, independent secular ground, a legislature could and might do all sorts of terrible things-for example, ban the use of all electrical devices on Sundays

12. See Michael J. Perry, Love and Power: The Role of Religion and Morality in AmeriCAN Politics 10 (1991) (criticizing Bruce Ackerman's conception of "neutral" political justification).

13. Cf. Michael W. McConnell, Political and Religious Disestablishment, 1986 BYU L. Rev. 405, 413 "Religious differences in this country have never generated the civil discord experienced in political conflicts over such issues as the Vietnam War, racial segregation, the Red Scare, unionization, or slavery."). 
(except, perhaps, those necessary to protect life or health) on the basis of a biblically grounded moral belief. But does anyone really believe that any legislative body in the United States-or in any other religiously pluralistic liberal democracy - would want to do such a thing, much less actually do it, even if there were no nonestablishment norm? Is the nonestablishment norm, construed to forbid government to disfavor conduct on the basis of a religiously grounded moral belief (unless there is a plausible, independent secular ground for the belief), really all that stands between us and such an extreme state of affairs? If the "parade of horribles" argument is the last resort of those who would defend the construal of the nonestablishment norm against which I have argued in this essay, I am content to rest my case.

The nonestablishment norm does not stand in the way-and, for the reasons I have given here, should not be construed to stand in the way — of legislators or other policymakers outlawing or otherwise disfavoring conduct on the basis of a religiously grounded belief that the conduct is immoral, even if it is assumed that the belief lacks a plausible, independent secular ground.

\section{The Morality of Liberal Democracy}

Recall that in the opening paragraph of this essay I said that la conception Américaine de la laïcité consists principally of the nonestablishment norm and of the law that the U.S. Supreme Court has developed in the course of enforcing the norm. Principally - but not exclusively: In addition to the nonestablishment norm, there is what we may call "the morality of liberal democracy." I now want to move beyond the nonestablishment norm to address a question that is important not just to citizens of the United States but to those of any liberal democracy, even one whose fundamental law does not forbid government to establish religion: Do legislators or other policymakers violate the morality of liberal democracy by outlawing or otherwise disfavoring conduct on the basis of religiously grounded moral belief? Even if government officials do not violate the nonestablishment norm by disfavoring conduct on the basis of religiously grounded moral belief, it may nonetheless be the case that they betray the morality of liberal democracy by doing so. That we are constitutionally free to do something-utter racial epithets, for example — does not entail that as a moral matter we should do it. In my judgment, however, government, by disfavoring conduct on the basis of religiously grounded moral belief, runs afoul neither of the nonestablishment norm nor, as I shall now explain, of the morality of liberal democracy. 
Disfavoring conduct on the basis of religiously grounded moral belief does not, in and of itself, betray either of liberal democracy's two constitutive commitments. Nothing, either in the commitment to the true and full humanity of every person or in the allied commitment to certain basic human freedoms, forbids legislators or other policymakers to disfavor conduct on the basis of a religiously grounded moral belief just in virtue of the fact that the belief is religiously grounded. ${ }^{1+}$ Nicholas Wolterstorff is right that the morality of liberal democracy, properly understood, forbids no such thing. ${ }^{15}$

$[T]$ he ethic of the citizen in a liberal democracy imposes no restrictions on the reasons people offer in their discussion of political issues in the public square, and likewise imposes none of the reasons they have for their political decisions and actions. If the position adopted, and the manner in which it is acted on, are compatible with the concept of liberal democracy, and if the discussion concerning the issue is conducted with civility, then citizens are free to offer and act on whatever reasons they find compelling. I regard it as an important implication of the concept of liberal democracy that citizens should have this freedom-that in this regard they should be allowed to act as they see fit. 'Liberal democracy implies, as I see it, that there should be no censorship in this regard. ${ }^{16}$

14. Recall that if the weaker claim cannot be sustained that, according to the morality of liberal democracy, one may not make a political choice disfavoring conduct on the basis of religiously grounded belief that the conduct is immoral, then it is unnecessary to focus on the stronger claim that in making the choice one may not rely on such belief at all.

15. I therefore disagree with John Rawls (and others, like Robert Audi) on this important point, as I have explained elsewhere. See also Michael J. Perry, Religion in Politics: Constitutional and Moral Perspectives 54-61 (1997) (explaining and criticizing Rawls' position).

16. Nicholas Wolterstorff, Audi on Religion, Politics, and Liberal Democtacy, in Robert Audi \& Nicholas Wolterstorff, Religion in the Public Square: The Place of Religious Convictions in Political Debate 145, 147 (1997). See also Laycock, supra note 5; Michael W. McConnell, Correspondence, Getting Along, First Thincs, June/July 1996, at 2. Cf. Sanford Levinson, Religious Language and the Public Square, 105 Harv. L. Rev. 2061, 2077 (1992) (reviewing Perry, supra note 12 , and suggesting that "liberal democracy [should] give everyone an equal right, without engaging in any version of epistemic abstinence, to make his or her arguments, subject, obviously, to the prerogative of listeners to reject the arguments should they be unpersuasive"). 
We can all agree, of course, that the morality of liberal democracy tolerates no formal (i.e., legal) censorship; Wolterstorff is right to insist that the morality of liberal democracy tolerates no informal (moral) censorship either.

Why, then, might one be inclined to conclude that government-in particular, legislators and other policymakers, acting collectively-should not disfavor conduct on the basis of religiously grounded moral belief? Two main reasons come to mind: the argument from respect and the argument from divisiveness.

The argument from respect can be understood as an argument based on the morality of liberal democracy, which is committed to the true and full humanity of every person and therefore grounds "the right [of every person] to equal respect." ${ }^{17}$ According to the argument from respect, for government to outlaw or otherwise disfavor conduct on the basis of religiously grounded moral belief is for government to act on the basis of a moral belief that some persons subject to the ban or regulation reasonably reject, and for government to do that is for it to deny to those persons the respect that is their due as persons-or, as John Rawls has put it, as "free and equal" persons. ${ }^{18}$ (Although this claim could be directed just at political reliance on religiously grounded moral belief, it is typically directed at political reliance on controversial moral belief whether or not religiously grounded.) This claim frequently appears, in one guise or another, in essays purporting to present the "liberal" position on the issue of morality's proper role in politics. For example, Stephen Macedo has written that " $t]$ he liberal claim is that it is wrong to seek to coerce people on grounds that they cannot share without converting to one's faith." ${ }^{19}$ Notwithstanding the frequency of its appearance, this "liberal" claim is deeply problematic.

Consider William Galston's response to the claim (as he understands the claim):

[Charles] Larmore (and Ronald Dworkin before him) may well be right that the norm of equal respect for persons is close to the core of contemporary liberalism. But while the (general) concept

17. Charles Larmore, The Moral Basis of Political Liberalism, 96 J. PHIL. 599, 621 (1999) (“The familiar constitutional rights of free-expression, property, and political participation, though no doubt serving to promote the goal of democratic self-rule, also have an independent rationale. They draw upon that most fundamental of individual rights, which is the right to equal respect.").

18. John Rawls, Political Liberalism 217 (1993).

19. Stephen Macedo, Transformative Constitutionalism and the Case of Religion: Defending the Moderate Hegemony of Liberalism, 26 PoL. THEORY 56, 71 (1998). 
of equal respect may be relatively uncontroversial, the (specific) conception surely is not. To treat an individual as person rather than object is to offer him an explanation. Fine; but what kind of explanation? Larmore seems to suggest that a properly respectful explanation must appeal to beliefs already held by one's interlocutors; whence the need for neutral dialogue. This seems arbitrary and implausible. I would suggest, rather, that we show others respect when we offer them, as explanation, what we take to be our true and best reasons for acting as we do. ${ }^{20}$

Galston's response needs to be both corrected and amended. First, the correction: Galston misconceives Larmore's position, which is that political "justification must appeal, not simply to the beliefs that the other happens to have, but to the beliefs he has on the assumption (perhaps counterfactual) that he affirms the norm of equal respect [for persons]."21 Larmore subsequently affirmed this aspect of his position: "The terms of political association are to be judged by reference to what citizens would accept, were they reasonable and committed to the principle of equal respect for persons." 22

Now, two crucial but friendly amendments to Galston's response: First, it is never for one to show respect for another for him to offer to her-for example, for a Nazi to offer to a Jew - an explanation to the effect that "You are not truly or fully human," even if the Nazi sincerely takes that to be his best reason for acting as he does. Second, respect counsels not only that we offer others, as explanation, what we take to be our best reasons for acting as we do, but also that we try to discern and then communicate to them whatever reason or reasons they might have for supporting —or, at least, for being less hostile to- the law or policy at issue. Christopher Eberle has developed and defended this important point. As Eberle emphasizes, however, respect requires that we try to discern and then communicate such reasons. It does not require that if we fail in the effort, we restrain ourselves from acting as-from supporting the law or policy that-otherwise we would. ${ }^{23}$

20. William A. Galston, Liberal Purposes 109 (1991).

21. Michael J. Perry, Religious Morality and Political Choice: Further Thoughts-and Second

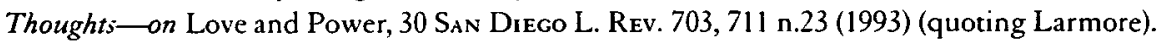

22. Larmore, supra note 17, at 611 (emphasis added).

23. This is a simplification of the position. Eberle develops and defends this important position with great care in his excellent book. Christopher J. Eberle, Religious Conviction in Liberal Politics (2002). 
Robert Audi has been one of the most thoughtful contributors to the literature about the proper role of religion in politics. ${ }^{2+}$ In his variation on the "liberal" position, Audi writes: "If you are fully rational and I cannot convince you of my view by arguments framed in the concepts we share as rational beings, then even if mine is the majority view I should not coerce you." ${ }^{25}$ But why? I concur in Gerald Dworkin's observation:

There is a gap between a premise which requires the state to show equal concern and respect for all its citizens and a conclusion which rules out as legitimate grounds for coercion the fact that a majority believes that conduct is immoral, wicked, or wrong. That gap has yet to be closed. ${ }^{26}$

Indeed, it is doubtful that the gap can be closed. It is altogether obscure why we do not show others the respect that is their due, first, "when we offer them, as explanation, what we take to be our best reasons for acting as we do" ${ }^{27}$ (so long as our reasons do not assert, presuppose, or entail the inferior humanity of those to whom the explanation is offered) and, second, when we try (even if in the end we fail) to discern and communicate other reasons that might win their consent, or at least diminish their hostility, to the law or policy at issue. ${ }^{28}$

The argument from divisiveness provides a second main reason why one might be inclined to conclude that government should not outlaw or otherwise disfavor conduct on the basis of religiously grounded moral belief: The social

24. See, e.g., Robert Audi, Religious Commitment and Secular Reason 197-99 (2000) (exploring the idea that many people rely on both religious and secular considerations about the status of a fetus in abortion law).

25. Robert Audi, The Place of Religious Argument in a Free and Democratic Society, 30 S An Diego L. Rev. 677, 701 (1993). I wonder what it means to be "fully rational"-and also what "concepts we share as rational beings."

26. Gerald Dworkin, Equal Respect and the Enforcement of Morality, 7 Soc. PhIL. \& Pol'y 180 , 193 (1990) (criticizing Ronald Dworkin). See also John Finnis, Natural Law and Natural Rights 221-22 (1980) (criticizing Ronald Dworkin). I concur in Nicholas Wolterstorffs critique of Audi's position on this point. Wolterstorff, supra note 16, at 159-61. It seems to me that in his recent essay on "the moral basis of political liberalism," Larmore fails to close the gap to which Gerald Dwork in refers. See Larmore, supra note 17, at 608 \& n. 13.

27. Galston, supra note 20, at 109.

28. Put another way, it is altogether obscure why one does not show her compatriots the respect that is their due when she adheres to what Christopher Eberle calls "the ideal of conscientious engagement." EBerLe, supra note 23, at 104; see id. at 104-08. 
costs-costs mainly in the form of divisiveness and ensuing social instability-are too high. Let me put the argument from divisiveness, as we may call it, in context: In the United States and in kindred liberal democracies, freedom of religion enjoys vigorous constitutional protection; therefore, the set of moral beliefs on which government may base a political choice is limited. For example, government may not base a political choice on the belief that Roman Catholicism is a morally corrupt religion. In thinking about the argument from divisiveness, then, let's focus not on moral beliefs on which government constitutionally may not base a political choice-least of all a coercive political choice-but on moral beliefs on which it constitutionally may base a political choice.

It is implausible that in a liberal democracy like the United States, basing a political choice on a constitutionally optional but nonetheless controversial moral belief will usually be more divisive if there is only a religious ground for the belief than if there is a secular ground (whether or not there is also a religious ground). As American history makes clear, some issues are so controversial that any political resolution of the issue is destined to be quite divisive without regard to whether the basis of the resolution is solely religious or solely secular or partly religious and partly secular. ${ }^{29}$ Even if we assumed that some imaginable instances of political reliance on religiously grounded moral belief might, with other factors, precipitate social instability, the fact remains that " $[c]$ onditions in modern democracies may be so far from the conditions that gave rise to the religious wars of the sixteenth century that we no longer need worry about religious divisiveness as a source of substantial social conflict." ${ }^{30}$ The American Jesuit theologian John Courtney Murray warned against "project[ingl into the future of the Republic the nightmares, real or fancied, of the past." ${ }^{\text {"1 }}$ As Murray's com-

29. The argument from divisiveness, unlike the argument from respect, is a consequentialist argument. One might be tempted to mount a more complicated version of the argument, according to which even if basing a political choice on a controversial moral belief will not usually be more divisive if there is only a religious ground for the belief than if there is a secular ground, the fact remains that the totality of the good consequences minus the totality of the bad consequences of basing a political choice on a controversial moral belief that has a secular ground is a number that is greater than the number reached by subtracting the totality of the bad consequences from the totality of the good consequences of basing a political choice on a controversial moral belief that has only a religious ground. But so far as I know, no one has tried to make an argument in support of that claim-a claim that in any event would be difficult to sustain.

30. Lawrence B. Solum, Faith and Justice, 39 DePAUL L. Rev. 1083, 1096 (1990). Solum is stating the argument, not making it; indeed, Solum is wary of the argument. See id. at 1096-97.

31. John Courtney Murray, We Hold These Truths: Catholic Reflections on the AmeriCan Proposition 38-39 (Rowman \& Littlefield Publishers 2005) (1960). 
ment suggests, a rapprochement between religion and politics forged in the crucible of a time or place very different from our own is not necessarily the best arrangement for our time and place. "[W] hat principles of restraint, if any, are appropriate may depend on time and place, on a sense of the present makeup of a society, of its history, and of its likely evolution." 32

In my judgment, neither the argument from respect nor the argument from divisiveness bears the weight of the proposition that government should not disfavor conduct on the basis of religiously grounded moral belief. (Not that there are no other arguments in support of that proposition, but the argument from respect and the argument from divisiveness are the two main arguments. ${ }^{33}$ ) Neither argument bears the weight even of the weaker proposition that government should not disfavor conduct on the basis of religiously grounded moral belief if there is no plausible, independent secular ground for the belief.

\section{Conclusion}

My aim here has been to explain why political reliance on religiously grounded moral belief does not violate American laïcité-why, that is, such reliance violates neither the nonestablishment norm nor even the morality of liberal democracy. This essay has now run its course.

32. Kent Greenawalt, Private Consciences and Public Reasons 130 (1995).

33. A third argument-call it the argument from alienation-bears mention: Reliance on religiously grounded moral belief as a basis of political decisionmaking makes many persons feel politically marginalized or alienated, namely, persons who do not subscribe to the supporting religious premise or premises. For Kent Greenawalt's version of the argument, see id. at 156-58. I have explained elsewhere why, in my judgment, the argument from alienation is implausible. See Perry, supra note 15, at 50-52 (criticizing Greenawalt's argument). Cf. Mark Tushnet, The Constitution of Religion, 18 Conn. L. Rev. 701, 712 (1986) ("IN]onadherents who believe that they are excluded from the political community are merely expressing the disappointment felt by everyone who has lost a fair fight in the arena of politics."). As Stephen Smith has explained:

$[T]$ he very concept of "alienation," or symbolic exclusion, is difficult to grasp. ... How, if at all, does "alienation" differ from "anger," "annoyance," "frustration," or "disappointment" that every person who finds himself in a political minority is likely to feel? "Alienation" might refer to nothing more than an awareness by an individual that she belongs to a religious minority, accompanied by the realization that at least on some kinds of issues she is unlikely to be able to prevail in the political process. That awareness may be discomforting. But is it the sort of phenomenon for which constitutional law can provide an efficacious remedy? Constitutional doctrine that stifles the message will not likely alter the reality-or a minority's awareness of that reality.

Steven D. Smith, Foreordained Failure: The Quest for a Constitutional Principle of ReliGIOUS FrEedoM 164 n.66 (1995) (citation omitted). 